\title{
Preparation and Characterization of Lanthanum Carbonate Octahydrate for the Treatment of Hyperphosphatemia
}

\author{
Anqi He, ${ }^{1}$ Fengshan Zhou, ${ }^{2}$ Fang Ye, ${ }^{3}$ Ying Zhang, ${ }^{1,4}$ Xiren He, ${ }^{5}$ \\ Xin Zhang, ${ }^{1,6}$ Ran Guo, ${ }^{1}$ Xing Zhao, ${ }^{5}$ Yan Sun, ${ }^{1,7}$ Ming Huang, \\ Qin Li, ${ }^{4}$ Zhanlan Yang, ${ }^{1}$ Yizhuang $X u,{ }^{1}$ and Jinguang $\mathrm{Wu}^{1}$ \\ ${ }^{1}$ College of Chemistry and Molecular Engineering, Peking University, Beijing 100871, China \\ ${ }^{2}$ School of Materials Science and Technology, China University of Geosciences, Beijing 100083, China \\ ${ }^{3}$ Beijing Coway Pharm. Co. Ltd., Beijing 100094, China \\ ${ }^{4}$ School of Medicine, Henan University, Kaifeng 471003, China \\ ${ }^{5}$ Tianjin Cenway Pharm. Co. Ltd., Tianjin 300480, China \\ ${ }^{6}$ College of Pharmacy, Liaoning University of Traditional Chinese Medicine, Shenyang 11660, China \\ ${ }^{7}$ College of Chemistry and Material Science, Hebei Normal University, Shijiazhuang 050024, China
}

Correspondence should be addressed to Fengshan Zhou; zhoufs@cugb.edu.cn and Yizhuang Xu; xyz@pku.edu.cn

Received 6 September 2013; Accepted 15 October 2013

Academic Editor: Isao Noda

Copyright (C) 2013 Anqi He et al. This is an open access article distributed under the Creative Commons Attribution License, which permits unrestricted use, distribution, and reproduction in any medium, provided the original work is properly cited.

\begin{abstract}
We proposed a new approach to prepare lanthanum carbonate via reactions between lanthanum chloride and $\mathrm{NaHCO}_{3}$. In the reaction, small amount of $\mathrm{NaHCO}_{3}$ solution was firstly added to the acidic lanthanum chloride solution to generate lanthanum carbonate nuclei and then $\mathrm{NaHCO}_{3}$ is added to the lanthanum chloride at a constant speed. This approach makes both precipitation reaction and neutralization reaction take place simultaneously. Consequently, lanthanum carbonate is produced at low $\mathrm{pH}$ environment ( $\mathrm{pH}$ below 4.0) so that the risk of generating lanthanum carbonate hydroxide is reduced. The product of the above reaction is validated by EDTA titration, elemental analysis, and XRD characterization. In addition, we established a FTIR spectroscopic method to identify $\mathrm{La}(\mathrm{OH}) \mathrm{CO}_{3}$ from $\mathrm{La}_{2}\left(\mathrm{CO}_{3}\right)_{2} \cdot 8 \mathrm{H}_{2} \mathrm{O}$. Lanthanum carbonate exhibits considerable ability to bind phosphate.
\end{abstract}

\section{Introduction}

Hyperphosphatemia is a complication of end stage renal failure. In healthy adults, the average daily intake of phosphate is around $1000-1500 \mathrm{mg}$, which is balanced by faecal and urinary outputs [1]. For patients with renal failure, however, the phosphate excretion ability of kidneys is reduced significantly. Consequently, the concentration of phosphate in the blood increases, leading to hyperphosphatemia [2]. Hyperphosphatemia causes secondary hyperparathyroidism, renal osteodystrophy, and other diseases. Moreover, high concentration of phosphate in serum results in the formation of calcium phosphate precipitates. Large amount of calcium phosphate precipitates deposited in blood vessels may lead to fetal cardiovascular and cerebrovascular problems in end stage renal failure patients [3].
Current treatment of hyperphosphatemia involves dietary phosphate restrictions, dialysis, and taking phosphate binder and vitamin D [3]. Most dietary phosphate is derived from protein, and the phosphate content has an almost linear correlation with protein intake. Dialysis patients have a higher dietary protein requirement than healthy persons [4]. It is difficult to rely on dietary restrictions to achieve control of phosphate. Moreover, dialysis provides inadequate removal of phosphate in serum. Therefore, renal failure patients have to take phosphate binders [5].

The use of phosphate binder began in the early 1970s [5] and the earliest phosphate binders are aluminum-based compounds. The drug is highly effective and cheap [1]. However, aluminum may accumulate in bone, brain, heart, and liver, causing aluminum toxicity in long-term use [6, 7]. Later, a calcium-based phosphate binder was developed. 
However, the efficacy of the calcium-based drug turned out to be lower than that of the aluminum-based compound. Moreover, calcium-based phosphate binder can cause hypercalcaemia and gastrointestinal adverse effects [2]. Therefore, ideal phosphate binders that are safe and highly effective in binding phosphate are needed [6].

Lanthanum carbonate is an ideal phosphate binder. It prevents the adsorption of dietary phosphate by forming insoluble lanthanum phosphate. It has been reported that lanthanum carbonate binds phosphate optimally at $\mathrm{pH} 3-$ 5 , while retaining binding activity at $\mathrm{pH} 1-7[8,9]$. In vitro studies suggest that the efficacy of lanthanum phosphate is comparable to that of aluminium compounds in binding with phosphate [1]. The FDA has approved that lanthanum carbonate can be utilized as a phosphate binder for renal failure patients.

Concerning the preparation of lanthanum carbonate, there are several approaches reported in the literature [10, 11]. However, these methods have unresolved problems. For example, it has been reported that lanthanum carbonate can be prepared by a reaction between $\mathrm{Na}_{2} \mathrm{CO}_{3}$ and $\mathrm{LaCl}_{3}$ in aqueous solutions. We notice that lanthanum ion possesses strong ability to bind hydroxide ion when the $\mathrm{pH}$ value of the aqueous solution is high. On the other hand, the $\mathrm{pH}$ value of an aqueous solution of $\mathrm{Na}_{2} \mathrm{CO}_{3}$ is rather high. As a result, the reaction between $\mathrm{Na}_{2} \mathrm{CO}_{3}$ and $\mathrm{LaCl}_{3}$ may produce undesirable $\mathrm{La}(\mathrm{OH}) \mathrm{CO}_{3}$ as a side product with lanthanum carbonate.

Although it has been reported that $\mathrm{La}(\mathrm{OH}) \mathrm{CO}_{3}$ can bind phosphate [12], $\mathrm{La}(\mathrm{OH}) \mathrm{CO}_{3}$ has not been approved by the FDA for the treatment of hyperphosphatemia. It has not been elucidated whether the $\mathrm{La}(\mathrm{OH}) \mathrm{CO}_{3}$ is safe in medical practice.

In this paper, we proposed a new approach to prepare lanthanum carbonate via reactions between $\mathrm{NaHCO}_{3}$ and $\mathrm{LaCl}_{3}$ in aqueous solution under low $\mathrm{pH}$ environment. In addition, the prepared lanthanum carbonate was characterized by using FTIR, XRD, elemental analysis, and titration methods. The ability of the lanthanum carbonate in binding phosphate was validated by spectrometric methods.

\section{Experimental}

2.1. Reagents. Lanthanum oxide ( $99.999 \%$ purity) was purchased from Jiaton technology company.

Hydrochloric acid ( $37 \mathrm{wt} \%, \mathrm{AR}$ ), sodium bicarbonate (AR), disodium salt of EDTA (AR), acetic acid (AR), and sodium acetate (AR) were purchased from Beijing Chemical Plant.

Zinc oxide (reference materials) was purchased from Beijing Institute of Chemical Reagents.

2.2. Instrument. Elemental analyses $(\mathrm{C}, \mathrm{H}, \mathrm{N})$ were performed on an Elementar Vario EL elemental analyzer.

$\mathrm{X}$-ray powder diffraction (XRD) data were recorded on a Rigaku D/Max-2000 diffractometer at $40 \mathrm{kV}, 100 \mathrm{~mA}$ for $\mathrm{Cu} \mathrm{K} \alpha$.

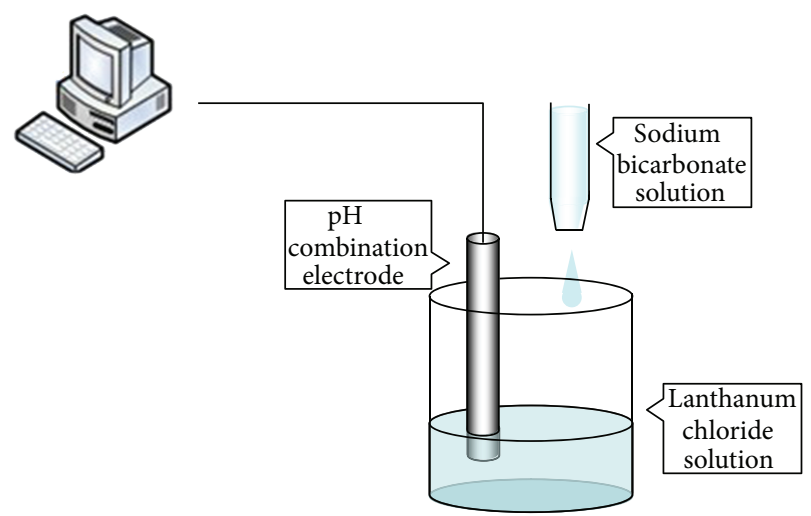

Scheme 1: Schematic diagram of the experimental setup on the reaction between lanthanum chloride and sodium bicarbonate.

FTIR spectra of $\mathrm{La}_{2}\left(\mathrm{CO}_{3}\right)_{3} \cdot 8 \mathrm{H}_{2} \mathrm{O}$ and $\mathrm{La}(\mathrm{OH}) \mathrm{CO}_{3}$ were collected on a Thermo-Fisher Nicolet iN10 MX FTIR spectrometer equipped with an IR microscope. The spectra were recorded under transmission mode at a resolution of $8 \mathrm{~cm}^{-1}$ and 64 scans were coadded.

Other FTIR spectra were recorded on a Fourier Transform Nicolet 6700 by using $\mathrm{KBr}$ pellets method. The spectra were recorded under transmission mode at a resolution of $2 \mathrm{~cm}^{-1}$ and 16 scans were coadded.

Quantitative analysis of phosphate was performed by using spectrophotometry $(\lambda=700 \mathrm{~nm})$ on a PE Lambda 35 UV-Vis spectrophotometer.

\subsection{Preparation}

2.3.1. Preparation of Lanthanum Carbonate. Lanthanum chloride was prepared via a reaction between lanthanum oxide and $\mathrm{HCl}$ solution. The initial concentration of $\mathrm{La}^{3+}$ was $1 \mathrm{~mol} / \mathrm{L}$ and the initial $\mathrm{pH}$ value of the solution was below zero. $\mathrm{NaHCO}_{3}$ was dissolved in deionized water, and the concentration of $\mathrm{NaHCO}_{3}$ of the obtained solution was $1 \mathrm{~mol} / \mathrm{L}$

Lanthanum carbonate was prepared by adding $\mathrm{NaHCO}_{3}$ solution into an aqueous solution of lanthanum chloride under stirring. Description and discussion on the experimental conditions in detail can be found in Section 3. During the reaction, the $\mathrm{pH}$ values of the reactive environment were measured by using a combination electrode. The data were converted into digital signal and collected into a desktop computer via a cluster communication port (Scheme 1).

2.3.2. Preparation of Lanthanum Carbonate Hydroxide. The obtained lanthanum carbonate was suspended in deionized water and the mixture was refluxed for 15 hours. Afterwards, the product was obtained via a filtration process.

2.4. Chemical Analysis of the Samples. The $\mathrm{La}^{3+}$ content of the samples was measured by using EDTA titration. The concentration of the EDTA solution was calibrated by using zinc oxide. 


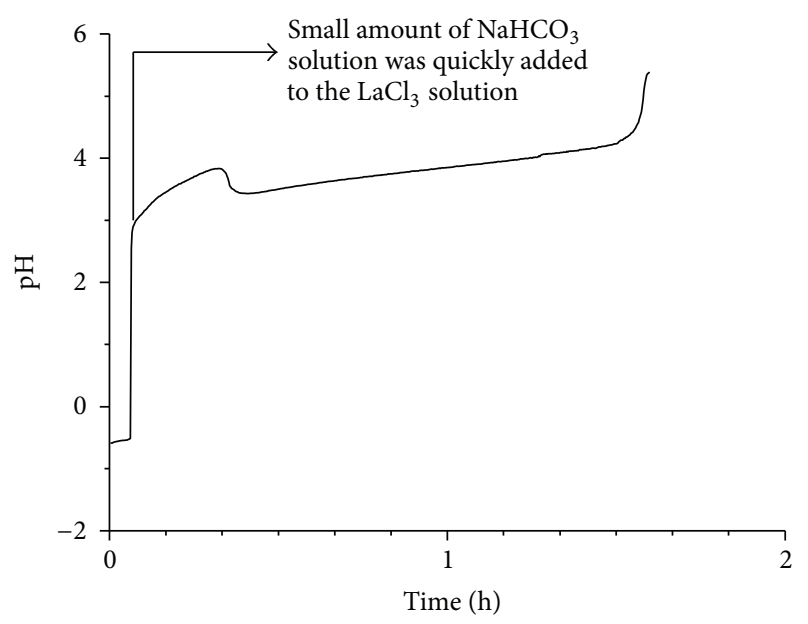

Figure 1: Variation of $\mathrm{pH}$ value as a function of time when $\mathrm{NaHCO}_{3}$ solution is added to $\mathrm{LaCl}_{3}$ solution at a rate of $0.2 \mathrm{~mL} / \mathrm{s}$.

\section{Results and Discussion}

When the sodium bicarbonate solution is added to the lanthanum chloride solution, the following two reactions cooccur in the system:

$$
\begin{gathered}
2 \mathrm{La}^{3+}+3 \mathrm{HCO}_{3}{ }^{-}=\mathrm{La}_{2}\left(\mathrm{CO}_{3}\right)_{3} \downarrow+3 \mathrm{H}^{+} \\
\mathrm{H}^{+}+\mathrm{HCO}_{3}{ }^{-}=\mathrm{H}_{2} \mathrm{O}+\mathrm{CO}_{2} \uparrow
\end{gathered}
$$

Reaction (1) is a precipitation reaction between $\mathrm{HCO}_{3}{ }^{-}$and $\mathrm{La}^{3+}$ and the products of the reaction are $\mathrm{La}_{2}\left(\mathrm{CO}_{3}\right)_{3}$ precipitates and proton. Reaction (2) is a neutralization reaction between $\mathrm{HCO}_{3}{ }^{-}$and $\mathrm{H}^{+}$. The precipitation reaction cannot be initiated without lanthanum carbonate nuclei being in the system while the acid-based neutralization reaction takes place as long as $\mathrm{H}^{+}$and $\mathrm{HCO}_{3}{ }^{-}$cooccur in the system. If the $\mathrm{NaHCO}_{3}$ solution was slowly added to the lanthanum chloride solution, the precipitation reaction cannot be initiated since no lanthanum carbonate nuclei occur in the system. As a result, only the neutralization reaction takes place in the system. Thus, the $\mathrm{pH}$ value of the system increases monotonically as more $\mathrm{NaHCO}_{3}$ solution is added. As a result, lanthanum carbonate is prepared at high-pH environment and the risk of producing lanthanum carbonate hydroxide increases considerably.

Herein, we propose an alternative approach to prepare lanthanum carbonate at lower $\mathrm{pH}$ environment. The approach is composed of three steps: (1) preparation of lanthanum carbonate nuclei, (2) preparation of lanthanum carbonate, and (3) termination of the reaction.

In the first step, small amount of $\mathrm{NaHCO}_{3}$ solution was quickly added to the lanthanum chloride solution. The concentration of $\mathrm{NaHCO}_{3}$ in the local regions is high enough so that lanthanum carbonate precipitates are formed. The produced lanthanum carbonate can be used as nuclei center and hence the bottleneck of the lack of lanthanum carbonate nuclei is removed. During the reaction, the variation of $\mathrm{pH}$ value is monitored and shown in Figure 1. When aqueous solution of $\mathrm{NaHCO}_{3}$ was quickly added, the $\mathrm{pH}$ value jumped around 3 . In the meantime, white precipitates of lanthanum carbonate appeared. Since $\mathrm{H}^{+}$was released from the precipitation reaction between $\mathrm{La}^{3+}$ and $\mathrm{HCO}_{3}{ }^{-}$, the decrease of $\mathrm{pH}$ can be observed in Figure 1. If no more $\mathrm{NaHCO}_{3}$ was added, the produced lanthanum carbonate can be dissolved completely by the acid produced from the reaction. To preserve the lanthanum carbonate nuclei, $\mathrm{NaHCO}_{3}$ solution was introduced into the system by using a ZDJ400 multifunctional titrimeter so that the injecting rate can be accurately controlled. The speed of injection of $\mathrm{NaHCO}_{3}$ solution was kept at $0.2 \mathrm{~mL} / \mathrm{s}$. During this process, more and more lanthanum carbonate precipitates were produced, while the $\mathrm{pH}$ value almost remained invariant. The reason for this phenomenon is that $\mathrm{NaHCO}_{3}$ plays a dual role in the system. On the one hand, $\mathrm{NaHCO}_{3}$ reacts with $\mathrm{La}^{3+}$ to produce lanthanum carbonate together with $\mathrm{H}^{+}$. On the other hand, $\mathrm{NaHCO}_{3}$ acts as a base that can neutralize $\mathrm{H}^{+}$. Since both precipitation reaction and neutralization reaction cooccur in the system, a dynamic equilibration on the concentration of $\mathrm{H}^{+}$is established and the $\mathrm{pH}$ value remains a constant during the reaction. It should be pointed out that the reaction is carried out at lower $\mathrm{pH}$ environment $(\mathrm{pH}$ is below 4.0) and the risk of producing $\mathrm{La}(\mathrm{OH}) \mathrm{CO}_{3}$ is significantly reduced.

When $\mathrm{La}^{3+}$ in the solution is completely consumed by the reaction, the precipitating reaction cannot be performed any more. However, the neutralization reaction can still be carried out. As a result, the $\mathrm{pH}$ value of the system jumped to 6 (Figure 1). To confirm that $\mathrm{La}^{3+}$ is used up at this moment, we collected small amount of supernatant from the system and added several drops of $\mathrm{NaOH}$ solution $(1 \mathrm{~mol} / \mathrm{L})$, and no $\mathrm{La}(\mathrm{OH})_{3}$ precipitate was observed, confirming that $\mathrm{La}^{3+}$ is completely consumed. Therefore, the reaction was stopped and the precipitate was collected as sample I.

The sample I was characterized by using XRD and the result is shown in Figure 2. The XRD pattern of the product matches with the $\mathrm{La}_{2}\left(\mathrm{CO}_{3}\right)_{3} \cdot 8 \mathrm{H}_{2} \mathrm{O}$. in ICDD PDF2-2004 database (card number: 25-1400) with a matching degree of $92.0 \%$. This result indicated that the product of the above reaction is $\mathrm{La}_{2}\left(\mathrm{CO}_{3}\right)_{3} \cdot 8 \mathrm{H}_{2} \mathrm{O}$.

The sample I was added to deionized water and the mixture was refluxed for 15 hours. Afterwards, the product was obtained after a filtration process and denoted as sample II. XRD pattern of sample II is shown in Figure 3. The XRD pattern matches with the $\mathrm{La}(\mathrm{OH}) \mathrm{CO}_{3}$ in ICDD PDF2-2004 database (card number: 26-0815) with a matching degree of $95.7 \%$. Thus, the product is proved to be $\mathrm{La}(\mathrm{OH}) \mathrm{CO}_{3}$.

Titration and elemental analysis results provide additional experimental evidence to support that the two samples are $\mathrm{La}_{2}\left(\mathrm{CO}_{3}\right)_{3} \cdot 8 \mathrm{H}_{2} \mathrm{O}$ and $\mathrm{La}(\mathrm{OH}) \mathrm{CO}_{3}$, respectively. The contents of lanthanum in the two samples were measured by EDTA titration. The contents of carbon were obtained by elemental analysis. The results of the above analysis are summarized in Table 1. Good agreement is found between the theoretical content and experimental results. From the chemical formula, we find that lanthanum carbonate and lanthanum carbonate hydroxide show significant difference on the molar ratio between carbon and lanthanum (denoted by $\left.n_{\mathrm{c}} / n_{\mathrm{La}^{3+}}\right)$. If the prepared sample is $\mathrm{La}_{2}\left(\mathrm{CO}_{3}\right)_{3}$, the $n_{c} / n_{\mathrm{La}^{3+}}$ 
TABLE 1: Results on the chemical analysis of sample I and sample II.

\begin{tabular}{lcccc}
\hline & \multicolumn{2}{c}{ Content of lanthanum } & \multicolumn{2}{c}{ Content of carbon } \\
& $\begin{array}{c}\text { Experimental value } \\
\left(\times 10^{-3} \mathrm{~mol} / \mathrm{g}\right)\end{array}$ & $\begin{array}{c}\text { Theoretical value } \\
\left(\times 10^{-3} \mathrm{~mol} / \mathrm{g}\right)\end{array}$ & $\begin{array}{c}\text { Experimental value } \\
\left(\times 10^{-3} \mathrm{~mol} / \mathrm{g}\right)\end{array}$ & $\begin{array}{c}\text { Theoretical value } \\
\left(\times 10^{-3} \mathrm{~mol} / \mathrm{g}\right)\end{array}$ \\
\hline Sample I & 3.293 & 3.322 & 4.98 & 4.98 \\
Sample II & 4.388 & 4.631 & 4.75 & 4.63 \\
\hline
\end{tabular}
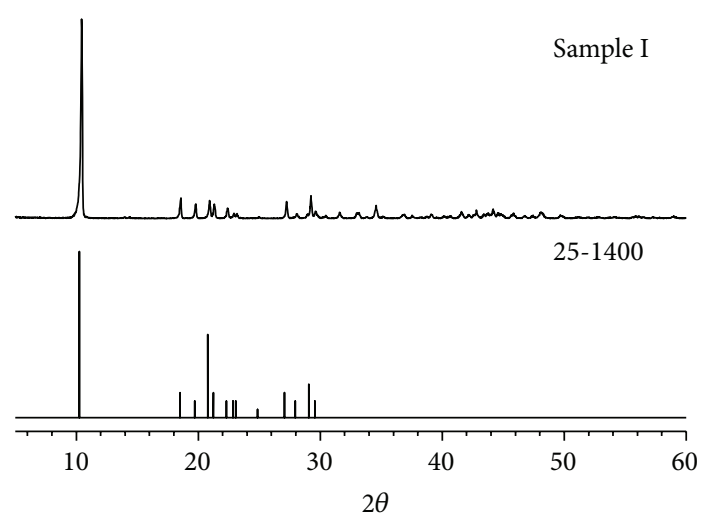

FIgURE 2: The XRD patterns of sample I and standard $\mathrm{La}_{2}\left(\mathrm{CO}_{3}\right)_{3} \cdot 8 \mathrm{H}_{2} \mathrm{O}$ from ICDD PDF2-2004 (card number: 25-1400). Match degree: $92.0 \%$.

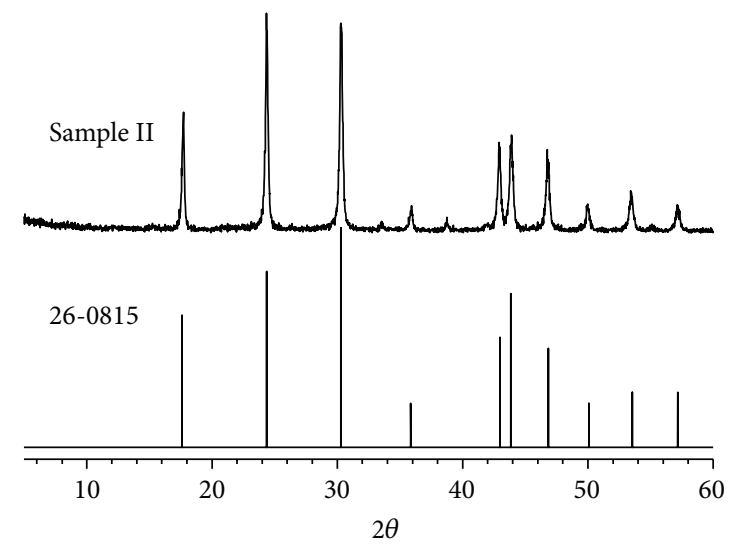

FIGURE 3: The XRD patterns of sample II and standard $\mathrm{La}(\mathrm{OH}) \mathrm{CO}_{3}$ from ICDD PDF2-2004 (card number: 26-0815). Match degree: $95.7 \%$.

should be $3 / 2=1.5$. If the sample was $\mathrm{La}(\mathrm{OH}) \mathrm{CO}_{3}$, the $n_{\mathrm{c}} / n_{\mathrm{La}^{3+}}$ should be $1 / 1=1$. The $n_{\mathrm{c}} / n_{\mathrm{La}^{3+}}$ values for sample I and sample II are 1.52 and 1.08 (Table 1), confirming that the products are lanthanum carbonate and lanthanum carbonate hydroxide, respectively.

Based upon the above result, we used the FTIR spectroscopic method to establish a rapid and reliable approach to identify lanthanum carbonate and lanthanum carbonate hydroxide.

FTIR spectrum of $\mathrm{La}_{2}\left(\mathrm{CO}_{3}\right)_{3} \cdot 8 \mathrm{H}_{2} \mathrm{O}$ is given in Figure 4 . For comparison, FTIR spectrum of $\mathrm{La}(\mathrm{OH}) \mathrm{CO}_{3}$ is also shown. Significant difference between the spectrum of $\mathrm{La}_{2}\left(\mathrm{CO}_{3}\right)_{3} \cdot 8 \mathrm{H}_{2} \mathrm{O}$ and that of $\mathrm{La}(\mathrm{OH}) \mathrm{CO}_{3}$ can be clearly

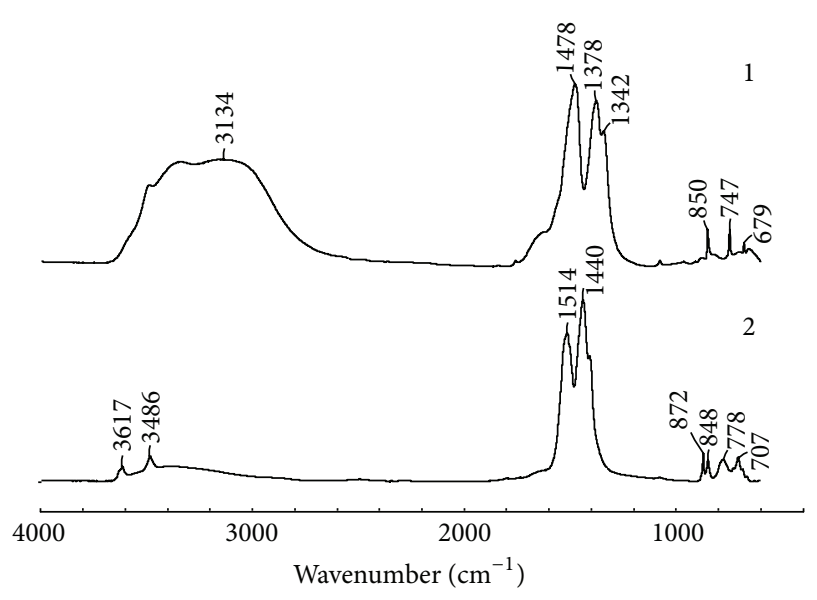

(a)

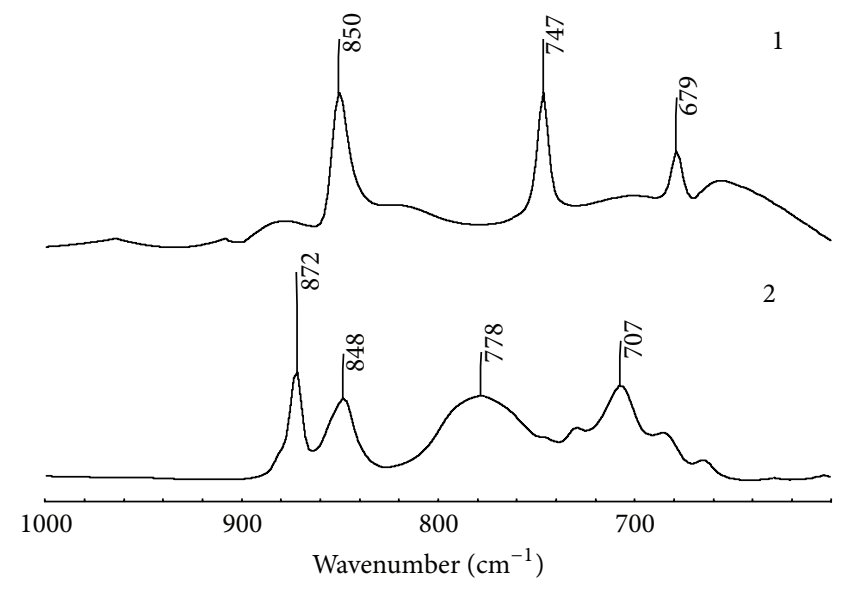

(b)

Figure 4: (a) FTIR spectra of $\mathrm{La}_{2}\left(\mathrm{CO}_{3}\right)_{3} \cdot 8 \mathrm{H}_{2} \mathrm{O}$ (line 1) and $\mathrm{La}(\mathrm{OH}) \mathrm{CO}_{3}$ (line 2). (b) FTIR spectra of $\mathrm{La}_{2}\left(\mathrm{CO}_{3}\right)_{3} \cdot 8 \mathrm{H}_{2} \mathrm{O}$ (line 1) and $\mathrm{La}(\mathrm{OH}) \mathrm{CO}_{3}$ (line 2) in the fingerprint region $\left(1000-600 \mathrm{~cm}^{-1}\right)$.

observed in the fingerprint region $\left(1000 \sim 600 \mathrm{~cm}^{-1}\right)$. $\mathrm{La}_{2}\left(\mathrm{CO}_{3}\right)_{3} \cdot 8 \mathrm{H}_{2} \mathrm{O}$ has sharp peaks at $850 \mathrm{~cm}^{-1}, 747 \mathrm{~cm}^{-1}$, and $679 \mathrm{~cm}^{-1}$, while $\mathrm{La}(\mathrm{OH}) \mathrm{CO}_{3}$ has absorption peaks at $872 \mathrm{~cm}^{-1}, 848 \mathrm{~cm}^{-1}, 778 \mathrm{~cm}^{-1}$, and $707 \mathrm{~cm}^{-1}$. The above dramatically different spectral features make it possible to detect $\mathrm{La}(\mathrm{OH}) \mathrm{CO}_{3}$ impurity in lanthanum carbonates. Here, different amount of $\mathrm{La}(\mathrm{OH}) \mathrm{CO}_{3}$ was mixed with $\mathrm{La}_{2}\left(\mathrm{CO}_{3}\right)_{3} \cdot 8 \mathrm{H}_{2} \mathrm{O}$, and FTIR spectra of the mixtures were collected by using $\mathrm{KBr}$ pellets method. Characteristic peak of $\mathrm{La}(\mathrm{OH}) \mathrm{CO}_{3}$ at $872 \mathrm{~cm}^{-1}$ can be observed when $5 \mathrm{wt} \%$ of $\mathrm{La}(\mathrm{OH}) \mathrm{CO}_{3}$ was mixed with $\mathrm{La}_{2}\left(\mathrm{CO}_{3}\right)_{3} \cdot 8 \mathrm{H}_{2} \mathrm{O}$ (Figure 5). To improve the sensitivity of the FTIR method, second 


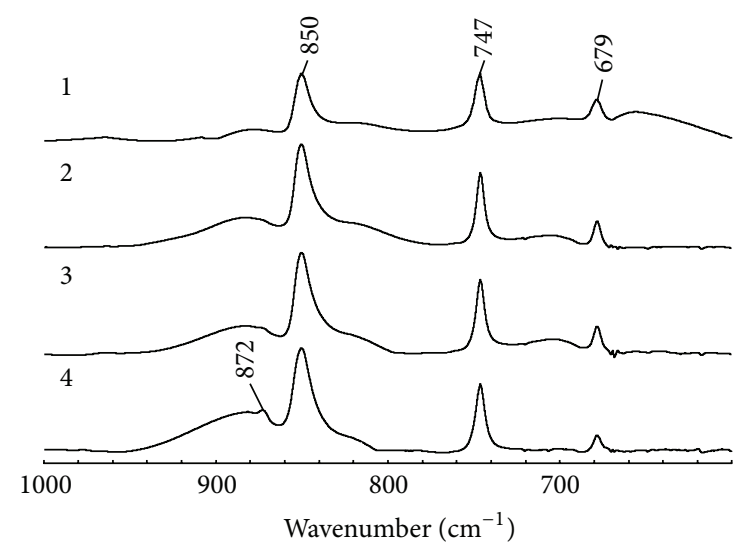

FIGURE 5: FTIR spectra of $\mathrm{La}_{2}\left(\mathrm{CO}_{3}\right)_{3} \cdot 8 \mathrm{H}_{2} \mathrm{O}$ (line 1), $\mathrm{La}_{2}\left(\mathrm{CO}_{3}\right)_{3} \cdot 8 \mathrm{H}_{2} \mathrm{O}$ containing $1 \mathrm{wt} \% \quad \mathrm{La}(\mathrm{OH}) \mathrm{CO}_{3}$ (line 2), $\mathrm{La}_{2}\left(\mathrm{CO}_{3}\right)_{3} \cdot 8 \mathrm{H}_{2} \mathrm{O}$ containing $2 \mathrm{wt} \% \mathrm{La}(\mathrm{OH}) \mathrm{CO}_{3}$ (line 3), and $\mathrm{La}_{2}\left(\mathrm{CO}_{3}\right)_{3} \cdot 8 \mathrm{H}_{2} \mathrm{O}$ containing $5 \mathrm{wt} \% \mathrm{La}(\mathrm{OH}) \mathrm{CO}_{3}$ (line 4) in the fingerprint region $\left(1000-600 \mathrm{~cm}^{-1}\right)$.

derivative spectra were utilized. In this case, characteristic peak of $\mathrm{La}(\mathrm{OH}) \mathrm{CO}_{3}$ at $872 \mathrm{~cm}^{-1}$ can be identified even if only $1 \mathrm{wt} \%$ of $\mathrm{La}(\mathrm{OH}) \mathrm{CO}_{3}$ was mixed with $\mathrm{La}_{2}\left(\mathrm{CO}_{3}\right)_{3} \cdot 8 \mathrm{H}_{2} \mathrm{O}$ (Figure 6).

To characterize the ability of lanthanum carbonate to bind phosphate, the following experiment was conducted: $0.2 \mathrm{~g}$ $\mathrm{KH}_{2} \mathrm{PO}_{4}$ was dissolved in $\mathrm{CH}_{3} \mathrm{COOH}-\mathrm{CH}_{3} \mathrm{COONa}$ solution (the concentrations of $\mathrm{CH}_{3} \mathrm{COOH}$ and $\mathrm{CH}_{3} \mathrm{COONa}$ are both $1 \mathrm{~mol} / \mathrm{L}$ ) so that $100.0 \mathrm{~mL} \mathrm{KH_{2 }} \mathrm{PO}_{4}$ solution whose $\mathrm{pH}$ value is around 4.7 was prepared. $0.5 \mathrm{~g} \mathrm{La}_{2}\left(\mathrm{CO}_{3}\right)_{3} \cdot 8 \mathrm{H}_{2} \mathrm{O}$ was added to the phosphate solution. Enough stirring was applied on the suspension. During the experiment, phosphate can be adsorbed by lanthanide carbonate so that the concentration of phosphate is decreased with time. To monitor the decay of the concentration of phosphate, small amount of supernatant was collected at different time and the concentration of phosphate in the supernatant was analyzed by using the Mo$\mathrm{Sb}$ antispectrophotometric method. Figure 7 shows the variation of the concentration of phosphate in the solution as a function of time. $50 \%$ phosphate is removed from the solution within $30 \mathrm{~min}$ and more than $95 \%$ phosphate is adsorbed by lanthanum carbonate within $120 \mathrm{~min}$. Considering the fact that food stays in the stomach for 4 hours, lanthanum carbonate is enough to bind most phosphate.

\section{Conclusion}

We proposed a new approach to prepare lanthanum carbonate via reactions between lanthanum chloride and $\mathrm{NaHCO}_{3}$. In the reaction, small amount of $\mathrm{NaHCO}_{3}$ solution was quickly added to the acidic lanthanum chloride solution to generate lanthanum carbonate nuclei. As a result, both precipitation reaction and neutralization reaction take place simultaneously. Lanthanum carbonate is produced at low $\mathrm{pH}$ environment ( $\mathrm{pH}$ below 4.0) so that the risk of generating lanthanum carbonate hydroxide is significantly reduced. EDTA titration, elemental analysis, and XRD characterization confirm that $\mathrm{La}_{2}\left(\mathrm{CO}_{3}\right)_{2} \cdot 8 \mathrm{H}_{2} \mathrm{O}$ are obtained

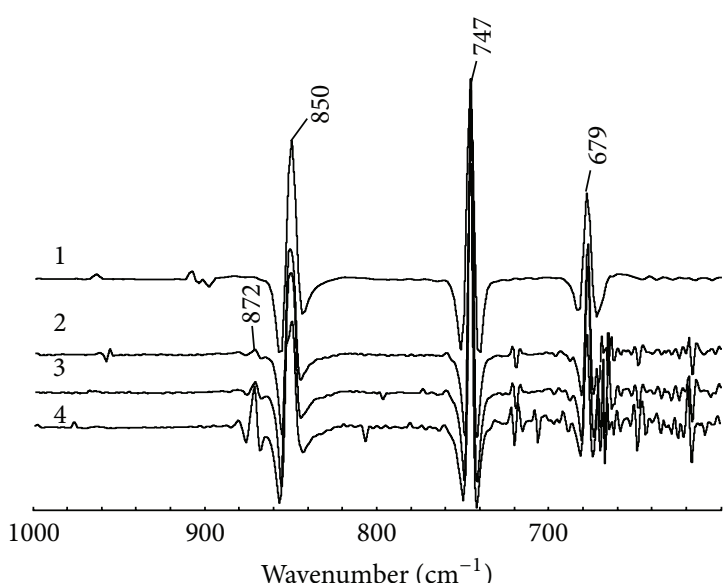

FIGURE 6: Second derivative FTIR spectra of $\mathrm{La}_{2}\left(\mathrm{CO}_{3}\right)_{3} \cdot 8 \mathrm{H}_{2} \mathrm{O}$ (line 1), $\mathrm{La}_{2}\left(\mathrm{CO}_{3}\right)_{3} \cdot 8 \mathrm{H}_{2} \mathrm{O}$ containing $1 \mathrm{wt} \% \mathrm{La}(\mathrm{OH}) \mathrm{CO}_{3}$ (line 2), $\mathrm{La}_{2}\left(\mathrm{CO}_{3}\right)_{3} \cdot 8 \mathrm{H}_{2} \mathrm{O}$ containing $2 \mathrm{wt} \% \mathrm{La}(\mathrm{OH}) \mathrm{CO}_{3}$ (line 3), and $\mathrm{La}_{2}\left(\mathrm{CO}_{3}\right)_{3} \cdot 8 \mathrm{H}_{2} \mathrm{O}$ containing $5 \mathrm{wt} \% \mathrm{La}(\mathrm{OH}) \mathrm{CO}_{3}$ (line 4) in the fingerprint region $\left(1000-600 \mathrm{~cm}^{-1}\right)$.

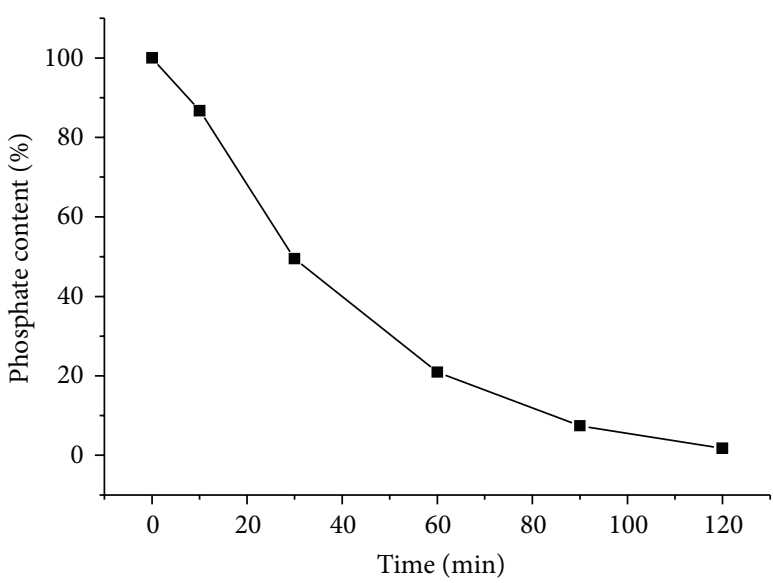

FIGURE 7: Variation of the concentration of phosphate in the supernatant as a function of time.

by using the above method. In addition, we established a method to identify $\mathrm{La}(\mathrm{OH}) \mathrm{CO}_{3}$ from $\mathrm{La}_{2}\left(\mathrm{CO}_{3}\right)_{2} \cdot 8 \mathrm{H}_{2} \mathrm{O}$. Small amount of $\mathrm{La}(\mathrm{OH}) \mathrm{CO}_{3}$ can be identified from $\mathrm{La}(\mathrm{OH}) \mathrm{CO}_{3} / \mathrm{La}_{2}\left(\mathrm{CO}_{3}\right)_{2} \cdot 8 \mathrm{H}_{2} \mathrm{O}$ mixture even if the content of $\mathrm{La}(\mathrm{OH}) \mathrm{CO}_{3}$ is only $1 \mathrm{wt} \%$. Lanthanum carbonate exhibits a considerable ability to bind phosphate.

\section{Conflict of Interests}

The authors declare that there is no conflict of interests regarding the publication of this paper.

\section{Acknowledgment}

This work is supported by the National Natural Science Foundation of China (51373003). 


\section{References}

[1] F. Albaaj and A. J. Hutchison, "Hyperphosphataemia in renal failure: causes, consequences and current management," Drugs, vol. 63, no. 6, pp. 577-596, 2003.

[2] T. Plagemann, A. Prenzler, and T. Mittendorf, "Considerations about the effectiveness and cost effectiveness of therapies in the treatment of hyperphosphataemia," Health Economics Review, vol. 1, no. 1, pp. 1-9, 2011.

[3] J. J. Schucker and K. E. Ward, "Hyperphosphatemia and phosphate binders," American Journal of Health-System Pharmacy, vol. 62, no. 22, pp. 2355-2361, 2005.

[4] D. D. Freitas, R. L. Donne, and A. J. Hutchison, "Lanthanum carbonate-a first line phosphate binder?" Current Opinion in Nephrology \& Hypertension, vol. 13, no. 6, pp. 403-409, 2004.

[5] J. A. Coladonato, "Control of hyperphosphatemia among patients with ESRD," Journal of the American Society of Nephrology, vol. 16, no. 11, pp. S107-S114, 2005.

[6] M. Tonelli, N. Pannu, and B. Manns, "Oral phosphate binders in patients with kidney failure," New England Journal of Medicine, vol. 362, no. 14, pp. 1212-1324, 2010.

[7] H. H. Malluche and H. Mawad, "Management of hyperphosphataemia of chronic kidney disease: lessons from the past and future directions," Nephrology Dialysis Transplantation, vol. 17, no. 7, pp. 1170-1175, 2002.

[8] S. P. Fricker, "The therapeutic application of lanthanides," Chemical Society Reviews, vol. 35, no. 6, pp. 524-533, 2006.

[9] B. A. Murrer and N. A. Powell, "Pharmaceutical composition containing selected lanthanum carbonate hydrates," Patent US 5968976, 1999.

[10] B. A. Murrey and N. A. Powell, "Pharmaceutical composition containing selected lanthanum carbonate hydrates," Patent CN 96193918.4, 1996.

[11] P. Jeevanandam, Y. Koltypin, O. Palchik, and A. Gedanken, "Synthesis of morphologically controlled lanthanum carbonate particles using ultrasound irradiation," Journal of Materials Chemistry, vol. 11, no. 3, pp. 869-873, 2001.

[12] J. C. Ferdinando and D. Gilmour, "Method of treating hyperphosphataemia using lanthanum hydroxyl carbonate," Patent CN 200580030985.1, 2772005. 

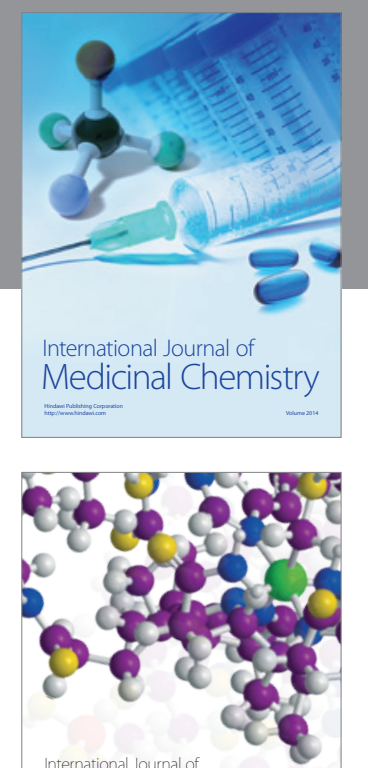

\section{Carbohydrate} Chemistry

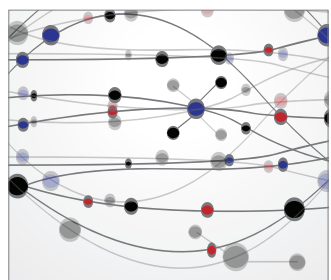

The Scientific World Journal
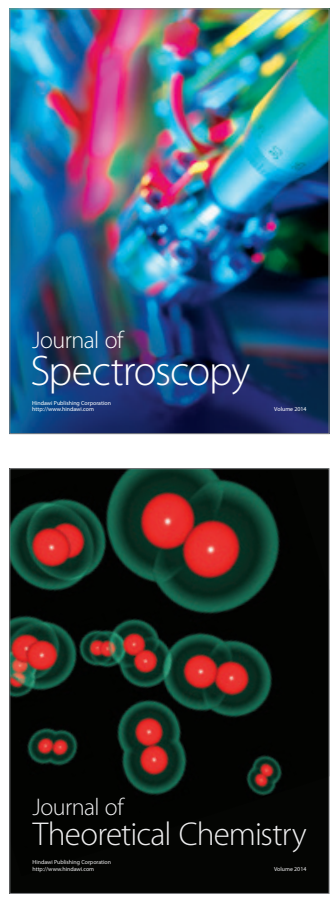
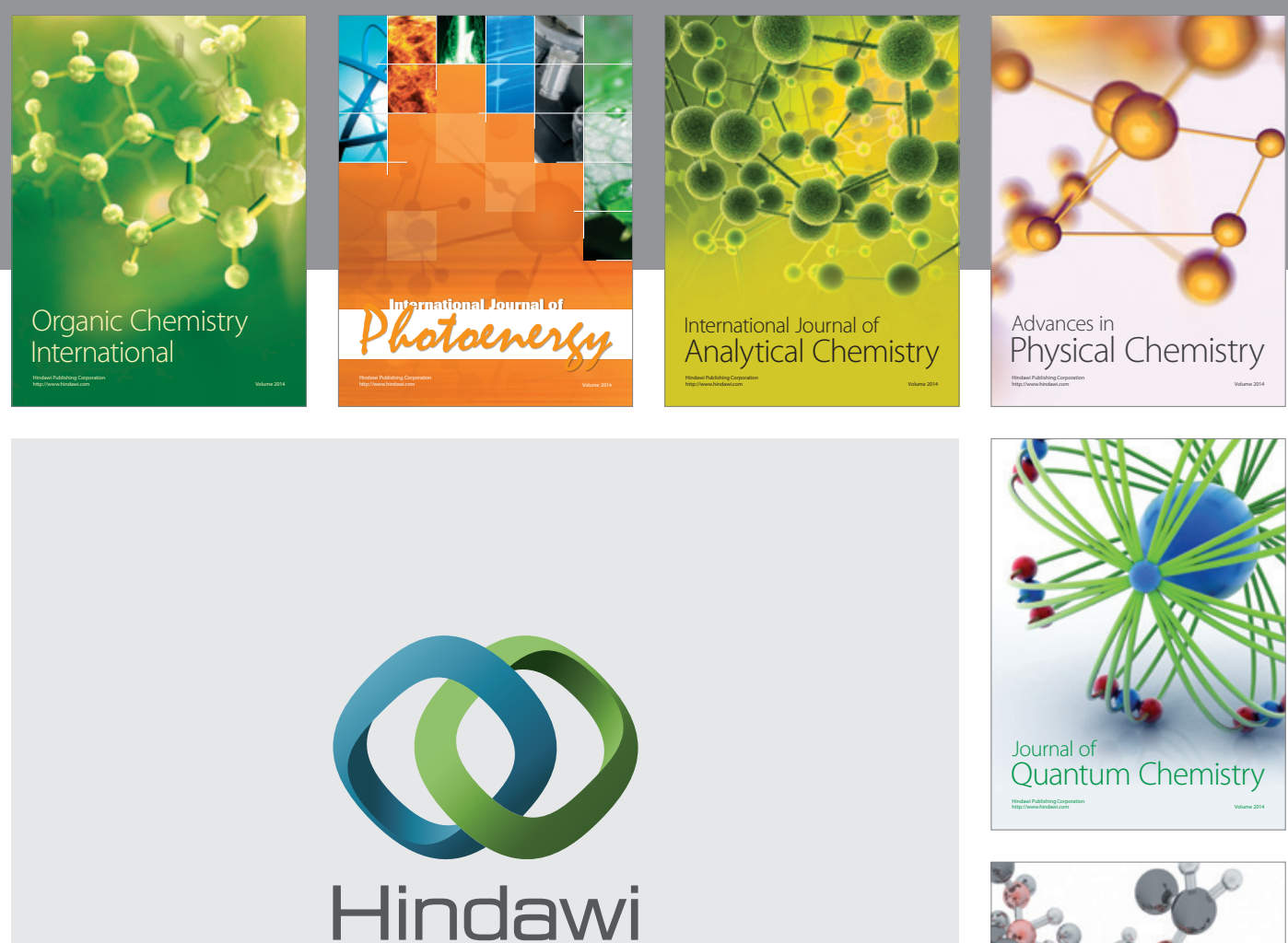

Submit your manuscripts at

http://www.hindawi.com

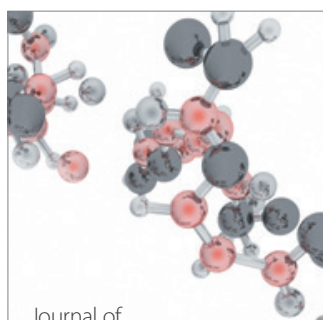

Analytical Methods

in Chemistry

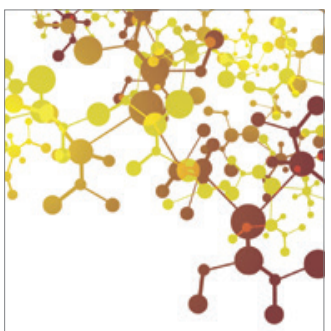

Journal of

Applied Chemistry

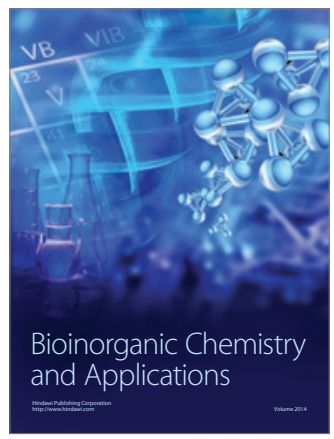

Inorganic Chemistry
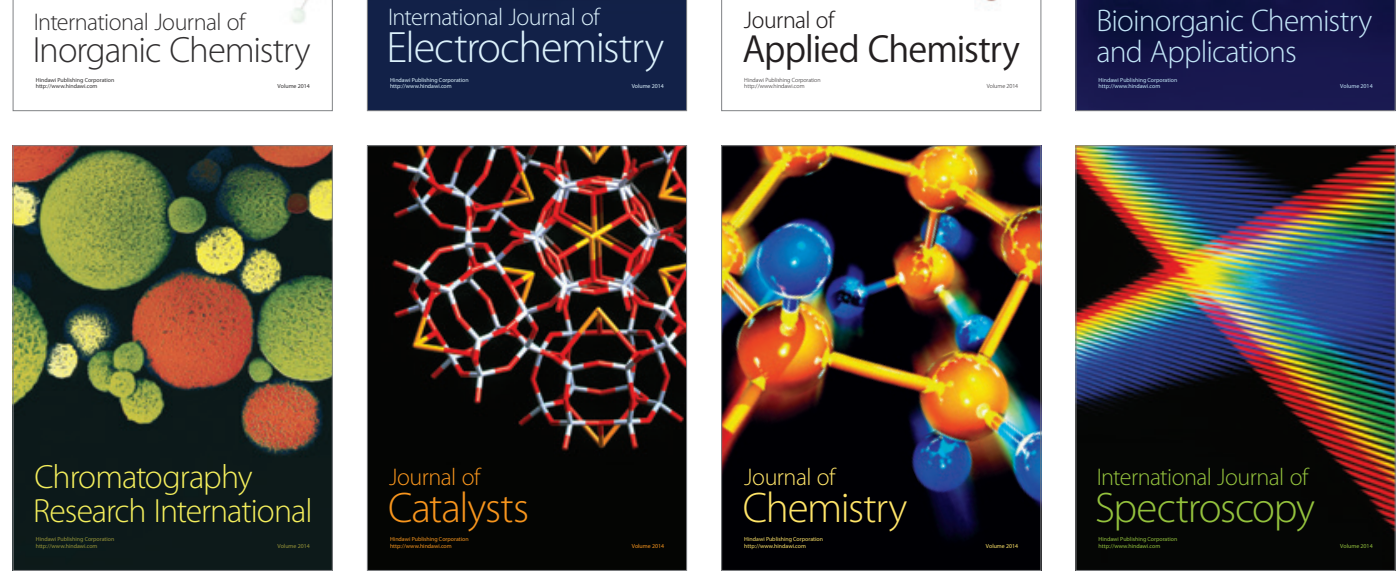